\title{
Removal Cyanobacteria by Diatomite Filter from Raw Freshwater and Potential Use in Watering Domestic Animals
}

\author{
Belkacem Behira \\ University of Es-senia, Faculty of Biology, Oran, Algeria
}

\section{Email address:}

behira1958@yahoo.fr

\section{To cite this article:}

Belkacem Behira. Removal Cyanobacteria by Diatomite Filter from Raw Freshwater and Potential Use in Watering Domestic Animals. Animal and Veterinary Sciences. Vol. 3, No. 3, 2015, pp. 80-83. doi: 10.11648/j.avs.20150303.11

\begin{abstract}
Growing harmful cyanobacteria in freshwater cause several poisoning episodes of livestock, wild and domestic animal. Conventional surface drinking water treatment utilizes coagulation; flocculation, sedimentation, filtration and disinfection are inadequate and require great financial means or application in watering domestic animals. The filtration of raw freshwater by diatomite is very simple without use of chemical products. Samples of locally diatomite were dried ant calcined and tested to verify their efficiency to removal cyanobacteria cells from raw freshwater. The results obtained shows that filtration by calcined diatomite improve high efficiency to removal cyanobacteria and decrease the level of microcystin in the filtrate solutions.
\end{abstract}

Keywords: Cyanobacteria, Diatomite, Removal, Raw Freshwater

\section{Introduction}

Cyanobacteria are a morphologically diverse group of photosynthetic prokaryotes that occupy a wide range of niches, from freshwater to hydrothermal vents, from desert rocks to Antarctic lakes. They most common toxic cyanobacteria in freshwater are Microcystis spp., Cylindrospermopsis raciborskii, Planktothrix (syn. Oscillatoria) rubescens, Synechococcus spp., agardhii, Gloeotrichia spp., Anabaena spp., Lyngbya spp., Aphanizomenon spp., Nostoc spp., some Oscillatoria spp., Schizothrix spp. and Synechocystis spp. Toxicity cannot be excluded for further species and genera (WHO,2003).

Temperature, light, and nutrients level and composition are the main factors affecting toxin production. Variation of cellular toxin levels under different growth conditions have been studied mainly with the batch cultures of Microcystis, Oscillatoria, Anabaena, Anabaena, Aphanizomenon, and Planktothrix (Rapala 1998, Sivonen and Jones 1999). About $75 \%$ of all cyanobacteria sampled contain toxins. It is the huge conglomerations of cells that present a great concern of development of large blooms in late summer and early fall (Chorus et al. 2000). The production of cyanotoxins includes risks to human and animal health. Depending on the concentration in the aquatic environment, they can cause severe poisoning, produce chronic diseases such as cancer, and even lead to death. Cyanotoxins are thus an important group of chemical compounds, from the point of view of ecotoxicology, toxicology, and environmental chemistry(Bláha,2009): Several poisoning episodes of livestock, wild and domestic animals have been associated with the occurrence of cyanobacteria blooms in surface waters used for drinking (Stewart et al. 2008). Microcystins are the most frequently occurring and widespread of the cyanotoxins. Due to these adverse health effects, the World Health Organization established a provisional guideline of $1 \mu \mathrm{g} / \mathrm{L}$ for microcystin-LR in drinking water (WHO, 1998).Conventional surface drinking water treatment utilizes coagulation, flocculation, sedimentation, filtration and disinfection as basic methods. However, conventional treatment may need to be optimized for cyanotoxin removal, relating to the form of the toxin to be removed (intra- or extracellular), the background water matrix, and possible dissolved toxin release during the treatment process (Falconer, 2005).In agreement with earlier findings that alum flocculation, filtration, and chlorination are ineffective in the removal of cyanobacteria toxins (Vuori et al. 1992). Physicochemical water treatment processes have been shown to cause cell lysis and toxin release (James and Fawell, 1991). Diatomite is a natural material formed from 
the remains of diatoms, which grew and were deposited in seas or lakes. The structure of diatomite is quite complex. Because there are many fine microscopic pores, cavities, and channels, it has a large specific surface area, high absorption capacity, and low density. Moreover, because of its relative low cost and abundance, it is utilized extensively as a filler, a filtering aid, an abrasive, an insulating material, a conventional catalyst support, and a membrane. Small, highly porous diatomite particles are useful in fabricating highly permeable microporous membrane filters (Vasconcelos et al., 2000). Diatomite was used in purification potable water, contaminated ground- and surface water, decontamination of sewage liquids and waste water. (Grešovnik, 2007).

The aim of this work is to test the natural and calcined diatomite as filter without chemical products use to removal cyanobacteria from raw water in watering domestic animals.

\section{Materials and Methods}

The raw diatomite obtained from (Sig deposit, Algeria) under investigation was subjected to treatment under various conditions. The first sample is the natural sample (S1). The second one (S2) is treated by $0.5 \mathrm{~N} \mathrm{Hcl}$, then washed by distilled water and finally dried in drying oven at $110{ }^{\circ} \mathrm{C}$ for 5 hours. The third one (S3) is calcined diatomite at $500{ }^{\circ} \mathrm{C}$ using muffle furnace. While the fourth (S4) is calcined at $700{ }^{\circ} \mathrm{C}$. All samples milled in a ball mill machine and sieved below $200 \mu \mathrm{m}$ to remove all particles larger than $200 \mu \mathrm{m}$. ideally, these fractions contain sand, rocks, clay, and other impurities. Raw water collected from eutrophic lake was used in this experiment. A pre-filtration was occurred on fine sand to removal microalgae and other large particular matters. To achieve filtration, 10 grams of diatomite were added in funnel and the pre-filtered water and one liter was filtered through the diatomite filter. The quantification and identification of cyanobacteria was determined by inverted microscopic. The morphological identification of cyanobacteria was done according to (Komárek and Zapomelova 2008). The determination of intracellular and the extracellular microcystin concentration in extracted samples was determined by HPLC following the method of Lawton et al, (1994). All chemicals used were HPLC grade. The stationary phase was a Symmetry C18 column $(250 \mathrm{x}$ $4.6 \mathrm{~mm}$ I.D., $5 \mu \mathrm{m}$ particle size, Waters) at a flow rate of $1 \mathrm{ml} \mathrm{min-1}$ and column temperature 38 o $\mathrm{C}$. The mobile phase were Milli-Q water (solvent A) and acetonitrile (solvent B) both acidified with $0.05 \% \mathrm{v} / \mathrm{v}$ TFA. MC-LR stock solution was prepared by mixing MC-LR standard (Sigma) with methanol, and then it was centrifuged in 2000 RPM for 15 min. MC-LR standard solutions were prepared in different concentrations by adding desired volumes of stock solution to methanol. The prepared standard solutions were $0,01,0.1,0.2,0.4,0.6,0.8,1.0,2.0,4.0,5.0,10 ., 20$, 40,80 and $100 \mu \mathrm{g} / \mathrm{L}$ of concentrations.

All experiments were repeated three twice.
Table 1. cyanobacteria count in filtrate solutions (cell/ $\mathrm{ml}$ ).

\begin{tabular}{lllll}
\hline \multirow{2}{*}{ Sample } & \multicolumn{4}{l}{ cyanobacteria spp. } \\
\cline { 2 - 5 } & $\begin{array}{l}\text { microcystis } \\
\text { spp. }\end{array}$ & $\begin{array}{l}\text { anabaena } \\
\text { spp. }\end{array}$ & $\begin{array}{l}\text { Oscillatoria } \\
\text { spp }\end{array}$ & $\begin{array}{l}\text { Synechococcus } \\
\text { spp }\end{array}$ \\
\hline S1 & $2.10^{4}$ & $2.10^{3}$ & $2.10^{2}$ & 50 \\
S2 & $5.10^{3}$ & $2.10^{2}$ & 20 & 10 \\
S3 & 80 & 20 & 10 & 4 \\
S4 & 10 & 4 & 0 & 0 \\
\hline
\end{tabular}

S1: natural diatomite, S2: Diatomite trated by $0.5 \mathrm{~N}$ Hcland drying at $110^{\circ} \mathrm{C} ; \mathrm{S} 3$ : Diaomite calcined at $500^{\circ} \mathrm{C}$; S4: Diatomite calcined at $700{ }^{\circ} \mathrm{C}$.

\section{Result and Discussion}

The identification and quantification in sample of raw water before filtration show that the microcystis spp. was the predominant genus followed respectively by anabaena spp., Oscillatory sop.,Synechococcus spp. The colonial diameter of microcrystals spp. range from 300 to $400 \mu \mathrm{m}$. The length of filaments anabaena spp. range from 100 to $200 \mu \mathrm{m}$. Oscillatoria spp. The filament length range from 90 to $150 \mu \mathrm{m}$. The quantification of cyanobacteria was 6 . $10^{4}$ cells $/ \mathrm{ml}$ of microcystis spp, $4.10^{3} \mathrm{cell} / \mathrm{ml}$ of anabaena spp., $5.10^{2}$ cell $/ \mathrm{ml}$ of Oscillatoria spp. and $1.10^{2}$ cells $/ \mathrm{ml}$ of Synechococcus spp. The quantification of cyanobacteria in the filtrate solution flirted through the naturally diatomite ( $\mathrm{S} 1$ ) shows that the number of microcystiis $s p p$. decrease at $8.10^{2}$ cell $/ \mathrm{ml}$, anabaena spp. at $2.10^{3}$ cell $/ \mathrm{ml}$, Oscillatoria spp. at $2.10^{2} \mathrm{cell} / \mathrm{ml}$ and Synechococcus spp. at $50 \mathrm{cell} / \mathrm{ml}$. For the diatomite treated by $0.5 \mathrm{Hcl}$ and dried at $110^{\circ} \mathrm{C}(\mathrm{S} 2)$, the numeration of cyanobacteria in the filtrate solution shows that the microcystis spp. was $6.10^{2}$ cell $/ \mathrm{ml}$, following by anabaena spp. $2.10^{2}$ cell $/ \mathrm{ml}$ and $20 \mathrm{cell} / \mathrm{ml}$ of Oscillatoria spp. The counting of the filtrate solution filtered through the calcined diatomite at $500{ }^{\circ} \mathrm{C}$ (S3) was 50 cell / $\mathrm{ml}$ of microcystis spp., 20 cell $/ \mathrm{ml}$ of anabaena spp., 10 cell $/ \mathrm{ml}$ of Oscillatoria spp., 4 cell/ $\mathrm{ml}$ of. For the filtrate solution collected from the filtration by calcined diatomite at $700{ }^{\circ} \mathrm{C}$, was detected only $10 \mathrm{cell} / \mathrm{ml}$ of microcystis spp. and $4 \mathrm{cell} / \mathrm{ml}$ of anabaena spp. The content of total microcystin LR in raw water reached 90 $\mu \mathrm{g} / \mathrm{L}$ in the same sample the extracellular microcystin $\mathrm{LR}$ was $1.6 \mu \mathrm{g} / \mathrm{L}$. The results of Total and extracellular microcystin in filtrate solutions were summarized in Tab. 2. the majors groups of cyanobacteria found in raw water from this eutrophic lake were microcystis spp. as the predominant genus. Microcystis genus is one of the most common bloom formers in freshwater systems on every continent except Antarctica. This genus can produce a suite of potentially harmful compounds (Fristachi and Sinclair, 2008). The Tab.1 shows that the retention of cells increases with diatomite processing method. The highest value was observed in the diatomite calcined at $700{ }^{\circ} \mathrm{C}$. median pore size of a calcined diatomite. Lange et al. (1986) found that the grade of diatomite used affected filter performance. For the finest diatomite grade with a median particle size of 7.5 
$\mu \mathrm{m}$, turbidity reduction was close to $100 \%$; however, for coarser grades with a median particle size of $22 \mu \mathrm{m}$, a $10 \%$ reduction was observed. The percent of retained cells of microcistis spp. increase at 33\% of initial microbial charge in raw diatomite filter (SI), this value increase at $80 \%$ in dried diatomite filter to reaching $0.01 \%$ by calcined diatomite filter ( S4). The high retention was observed at ossilatoria spp. $96 \%$ was removal by dried diatomite, $98 \%$ by calcined diatomite at $500{ }^{\circ} \mathrm{C}$ and $100 \%$ by calcined diatomite calcined at $700{ }^{\circ} \mathrm{C}$. This is probably explained by the morphology of the filament that can reach $100 \mu \mathrm{m}$ of long and the mucilage sheath. The estimation of total microcystin LR and the intracellular microcystin shows that this toxin was concentered in the cells. By subtracting, the intracellular microcystin was very high $(88.4 \mu \mathrm{g} / \mathrm{L})$ compared to extracellular microcystin LR content (1.6 $\mu \mathrm{g} / \mathrm{L})$. The high rates of dissolved microcystin in filtered lake water at the end of blooming season suggest that release of cyanotoxins from cells occurs during the senescence and the decomposition periods of Microcystis cells (Park et al. 1996). The results shows that the filtration by diatomite was not contributed to increase of microcystin content in all filtrates. However the use of chemical products increases the extracellular microcystin level in the freshwater treatment by lysis of cyanobacteria cells. In similar work Zhang et al.(2011) were tested bombon-based charcoal adsorbent modified with chitosan to removal microcystin from drinking water and their conclusion was the efficiency this product depends of the $\mathrm{pH}$ and the organic matters dissolved in water. The diatomite filter efficiency depending of the size of the pores of the diatomite filter and the size of cyanobacterial cell, so not affected by the chemical or the physical parameters of water. Compared to sample (S4), the difference between total microcystin LR and the extracellular microcystin LR in the three samples ( S1, S2, S3) is highly significant. the result of filtration shows that was conform to the guidance value for the maximal acceptable concentration of microcystin-LR in drinking water, $1 \mu \mathrm{g} / \mathrm{L}$ recommended by the WHO.

Table 2. content of total microcystin LR and extracellular in filtrate solutions $(\mu \mathrm{g} / \mathrm{L})$.

\begin{tabular}{lll}
\hline Sample Total & Total microcystin LR & $\begin{array}{l}\text { Extracellular microcystin } \\
\text { LR }\end{array}$ \\
\hline S1 & 4.5 & 0.9 \\
S2 & 10.5 & 0.7 \\
S3 & 4.0 & 0.5 \\
S4 & 0.6 & 0.5 \\
\hline
\end{tabular}

\section{Conclusion}

The diatomite is a product of choice to remove toxic cyanobacteria in raw water. Filtration through natural diatomite calcined at $700^{\circ} \mathrm{C}$ exhibits a high efficiency of filtration of all the colonial and filamentous forms of cyanobacteria. This method reduces the amount of microcystins in filtered water. This simple method can be applied in the reservoirs watering domestic animals. In rural areas this method is economic and easy.

\section{References}

[1] Bláha, L.; Pavel, B.; Blahoskav, M. (2009) Toxins produced in cyanobacterial water blooms-Toxicity and risks. Interdiscip. Toxicol. 2009, 2, 36-41

[2] Chorus I, Falconer I R, Salas H J and Bartram J. '(2000). Health risks caused by freshwater cyanobacteria in recreational waters. Journal of Toxicology and Environmental Health-Part B 3(4): 323-47.

[3] Falconer, I.R. (2005) Cyanobacterial toxins of drinking water supplies: cylindrospermopsins and microcystins. Boca Raton: CRC Press; 2005.

[4] Fristachi, A. and J.L Sinclair.(2008) Occurrence of cyanobacterial harmful algal blooms workgroup report. In: Hudnell, K.H. (Ed.), Cyanobacterial Harmful Algal Blooms: State of the Science and Research Needs. Springer, New York, pp. 45-103

[5] Grešovnik, I.(2007) The use of moving least squares for a smooth approximation of sampled data. Strojniški vestnik Journal of Mechanical Engineering, vol. 53, no. 9, p. 582-598

[6] James, H. and Fawell, J.K. (1991) Detection and Removal of Cyanobacterial Toxins from Freshwaters. Report No. FR0211 Foundation for Water Research, Marlow, UK.

[7] Komárek, J. and Zapomělová, E. (2008) Planktic morphospecies of the cyanobacterial genus Anabaena = subg. Dolichospermum -2 . part: straight types. Fottea, Olomouc, 8(1): 1-14, 2008

[8] Lange, K.P., Bellamy, W.D., Hendriks, D.W. and Logsdon, G.S.(1986) Diatomaceous earth filtration of Giardia cysts and other substances. J. Am. Water Works Assoc., 78(1): 76-84.

[9] Lawton, L.A., Edwards, C., and Codd, G.A. (1994) Extraction and high performance liquid Microcystis and amount of microcystin in Lake Suwa, Japan. In: Yasumoto T, Oshima Y, Fukuyo

[10] Park, H.D., Iwami, C., Watanabe, M.F., Harada, K.I, Okino, T., Hayashi; H.(1996) Seasonal changesof toxic population of the toxic cyanobacterium Microcystis spp. in Lake Wannsee (Germany). Microb. Ecol. 43:107-118

[11] Rapala J and Sivonen K. 1998. Assessment of environmental conditions that favour hepatotoxic and neurotoxic abaena spp. strains cultured under light limitation at different temperatures. Microbial Ecology 36(2): 181-92

[12] Sivonen K and Jones G. 1999. Cyanobacterial toxins. Toxic Cyanobacteria in Water: a Guide to Their Public Health Consequences, Monitoring and Management. Pp.41111.(Eds.) Chorus I and Bartram J E and FN Spon, London.

[13] Stewart, I., Seawright, A., Shaw, G.(2008) Cyanobacterial poisoning in livestock, wild mammals and birds - an overview. Adv Exp Med Biol 2008;619:613-37.

[14] Vasconcelos, P.V., Labrincha, J.A., and Ferreira, J.M.F.(2000) Permeability of diatomite layers processed by different colloidal techniques. J. Eur. Ceram. Soc. 20, 201 
[15] Vuori. E, Himberg, K., Waris, M., Niinivaara, K.(1992) Drinking water purifiers in removal of hepato- and neurotoxins produced by cyanobacteria. In: Recent Advances in Toxinology Research. Vol 3 (Gopalakrishnakone P, Tan CK, eds). Singapore:National University of Singapore, Venom and Toxin Research Group, 1992;318-32

[16] WHO .2003) Guidelines for safe recreational water environments Volume 1: Coastal and freshwaters. World Health Organization, Geneva, 2003.
[17] WHO.(1998) Cyanobacterial toxins: Microcystin-LR in Drinking-water. Background document for development of WHO Guidelines for Drinking-water Quality. Guidelines for drinking-water quality,. World Health Organization, Geneva,1 998.

[18] Zhang H, Zhu G, Jia X, Ding Y, Zhang M, Gao Q, Hu C, Xu (2011) Removal of microcystins-LR from drinking water using a bombon-based charcoal adsorbent modified with chitosan.. J Environ Sci (China). 2011;23(12):1983-8. 